\title{
Teachers' Opinions about Using Multiple-choice Questions in the National Examination of Mathematics: A Survey in Vietnam
}

\author{
Nguyen Phu Loc ${ }^{1, *}$, Duong Huu Tong', Tong Thanh Thoang², Nguyen Thi Lan Huong ${ }^{2}$, \\ Doan Thi Kim Ngan², Dang Thanh Tuan², Nguyen Trong Nhan ${ }^{2}$ \\ ${ }^{1}$ School of Education, Can Tho University, Vietnam \\ ${ }^{2}$ Master Student in Mathematics Education, School of Education, Can Tho University, Vietnam
}

Received November 13, 2019; Revised January 11, 2020; Accepted February 7, 2020

Copyright $\bigcirc 2020$ by authors, all rights reserved. Authors agree that this article remains permanently open access under the terms of the Creative Commons Attribution License 4.0 International License

\begin{abstract}
In Vietnam, after completing the high school education program, students who want to receive high school diploma, they must take a national examination including three compulsory subjects: Math, a foreign language, and Literature and electives in two groups: or Physics, Chemistry and Biology or History, Geography and Citizenship education. The method of exam-taking in the national examination greatly affected the teaching and learning style of teachers and students. In the process of teaching at high school, especially in the final year, the teachers studied how to ask types of question that have appeared in the national exam to focus on practising test-taking skills for students. Before 2017, the national examinations of Physics, Chemistry, Biology, Foreign Languages, Geography, History and Citizenship education consisted of all the multiple-choice questions; only in Math and Literature, essay questions were used. Since 2017, in national examinations of mathematics in Vietnam, there has been a significant change: the examinations with all essay questions with a time of 180 minutes (10 questions) were replaced by examinations with all multiple-choice questions (45 questions / 90 minutes). This change has met many conflicting opinions and has profoundly affected teachers' the method of teaching and reviewing knowledge and skills of mathematics for high school students in Vietnam. To better understand the perception of mathematics teachers who directly teach - about this change, we conducted a survey of 50 mathematics teachers. The results showed that they were fully aware of the advantages of multiple-choice question-based examinations, and most of them wanted to maintain the use of multiple-choice questions for the following years.
\end{abstract}

Keywords Multiple-choice Question, National Examination of Mathematics, Testing and Evaluation, Essay Question

\section{Introduction}

\subsection{Some Concepts on Evaluation and Examination}

Evaluation is the process of judging of calculating the quality, importance, amount, or value of something [8]. Educational evaluation is a process in which an educational and training procedure is compared with its predetermined goals to find out their fulfillment [7].

An examination is a formal test that a candidate "must pass in order to earn a particular qualification or to be allowed to do a particular job"[8]. Examinations form one of the most common tools around which entire systems of education revolve. Every educational system uses examination as an indicator of performance and examinations are used to promote learners to the next academic level.[10]

National Examination “ is a measuring tool used to determine the success standard of a learning process" [9]. According to Rijal Firdaos \& Ahmad (2018), a national examination is an evaluation of the achievement of educational programs and evaluation is an activity to know the achievement of a program. Sukyadi \& Mardini (2011) also shows that the national examination also has a significant influence on teachers' instruction "in the aspect of activity/time arrangement, teaching materials, teaching contents, teaching methods, teaching strategies, 
ways of assessing, and on the feelings and attitudes of the students" [11].

\subsection{Multiple-choice Question and Essay Question}

\section{Multiple-choice Question}

According to Centre for teaching excellence- University of Waterloo (Canada), multiple-choice questions are composed of one question (stem) with multiple possible answers (choices), including the correct answer and several incorrect answers (distractor) [3]. For these questions, Maryellen Weimer (2018) pointed out the advantages and disadvantages as follows:

Advantages: (1) "Easy to score, by hand or electronically; (2) Can be constructed so that they test higher-order thinking skill"s; (3) Can test widely content area on\ each examination. [4]

Disadvantages: (1) Can recognize the answer to a question despite the student knows little about the subject; (2) Can guess answers; (3) Take time and skill to construct high-quality questions [5].

\section{Essay question}

Essay question, according to Merriam - Webster Dictionary, is "an examination question that requires an answer in a sentence, paragraph, or short composition" [5]. According to Maryellen Weimer (2018), advantages of this question are ([4]): (1) Give students an opportunity to present knowledge, skills, and abilities in different ways; (2) Use to develop students writing skill, particularly "the ability to argue with support of reasoning and evidence" ([4]). And the disadvantages are (see [4]): (1) Require much time to grade; (2) Often assess the answers subjectively; (3) Take little time for students to revise their composition if used in class.

In this paper, we mention only two types of questions that have been used in the national mathematics examination in Vietnam: essay questions and multiple-choice questions with 4 options.

\section{The Research Purpose}

In Vietnam, the controversial problem is that mathematics in the national exam should use: (I) entire essay questions; (II) or entire multiple choice questions with 4 options. Before 2017, although many other subjects such as Physics, Biology, Chemistry used mode (II); notably, mathematics still used mode (I) - using essay questions for the exam because many experts argued that mathematics is a discipline of logical reasoning, so they objected to the form of objective tests. However, from 2017 to now, with the determination of the leaders of the Ministry of Education and Training, the national exams of mathematics have included a set of multiple-choice questions (45 questions in 90 minutes). At present, there are still oppositions and approvals of mode (II) of many experts and teachers. The main reason why many experts in mathematics are very opposed to applying mode (II) is that if using multiple-choice question-based tests in mathematics, students will lose their creativity and logical thinking (see[2]). Vu Dinh Hoa, a mathematician, argued that whether with multiple-choice or essay, good students will do well on the test. But if students do mathematics test of multiple-choice questions well, it will be not sure whether these students are really good at mathematics or $\operatorname{not}($ see $[2])$.

By contrast, those who favour the mode of the mathematics test with multiple-choice questions have their own arguments. Nguyen An Ninh, an expert in testing and evaluation, said that in order to answer correctly and quickly, candidates must master, and understand the theoretical knowledge learned within the program; at the same time, there must be experiences accumulated during mathematics practice; be capable of flexible and creative analysis of real mathematical situations (see[2]). Lam Quang Thiep, the former expert of the Ministry of Education and Training, insists that examination with multiple-choice questions, will surpass the many limitations of the essay exam such as comprehensive assessment of students' knowledge instead of only assessing a few parts of knowledge of the essay exam; students must study comprehensively instead of studying some content that they think will appear in the test as in the case of using the whole essay questions. In particular, the computer-based multiple-choice examinations will be objective, more accurate than the essay-based examination, which depends on the expertise of the examiner (see[1]). In this regard, Ngo Bao Chau, a famous mathematician, said that: "From the past until now, the examination of Mathematics in Vietnam or many countries has mainly been written, calculated, a little proved, though not very much. However, recently, the trend of some countries like the US has been taking Math by using multiple-choice questions " (see [6]).

The above are experts' very different opinions on examinations with multiple choice questions, but for mathematics teachers who directly teach mathematics in Grade 12 (the final year of high school), who have to review and guide students to take the national exam, what are their opinions? In order to make this clearer, we conducted the survey on opinions of teachers who have directly participated in teaching 12th-grade mathematics in recent years; from there, we can learn more teachers' perception about this type of test.

\section{Methodology}

\subsection{Survey Subjects}

we conducted a survey of 50 teachers directly 
participating in teaching $12^{\text {th }}$-grade mathematics in the provinces of Mekong Delta region - Vietnam; all of them are studying a master program in Mathematics Education of Can Tho University, Vietnam. The contents surveyed are:

- Difficulties of teaching in a case of using multiple-choice questions in national examinations of mathematics;

- Comments about creating the test using multiple choice questions in mathematics;

- $\quad$ Students' learning attitudes in a case of using multiple-choice questions in examinations;
- $\quad$ Effectiveness of using multiple-choice questions in national examinations of mathematics;

- Comments on the use of the types of questions in national examinations of mathematics.

\subsection{Data Collecting and Analyzing}

- Using 5 questionnaires

- Analyzing data by descriptive statistics and qualitative method.

\subsection{Survey Time: the academic year $2018-2019$.}

\section{Results and Discussion}

Table 1. Difficulties of teaching in a case of using multiple-choice questions

\begin{tabular}{|c|l|c|c|c|c|c|}
\hline \multicolumn{1}{|c|}{ Items } & $\begin{array}{c}\text { Strongly } \\
\text { disagree }\end{array}$ & Disagree & Neutral & Agree & Strongly agree \\
\hline \multirow{2}{*}{1} & $\begin{array}{l}\text { It takes a lot of time to prepare lessons and } \\
\text { questions }\end{array}$ & $\begin{array}{c}1 \\
(2 \%)\end{array}$ & $\begin{array}{c}9 \\
(18 \%)\end{array}$ & $\begin{array}{c}6 \\
(12 \%)\end{array}$ & $\begin{array}{c}27 \\
(54 \%)\end{array}$ & $\begin{array}{c}7 \\
(14 \%)\end{array}$ \\
\hline \multirow{2}{*}{2} & $\begin{array}{l}\text { Using teaching methods that are appropriate } \\
\text { to the multiple-choice based testing }\end{array}$ & $\begin{array}{c}0 \\
(0 \%)\end{array}$ & $\begin{array}{c}5 \\
(10 \%)\end{array}$ & $\begin{array}{c}9 \\
(18 \%)\end{array}$ & $\begin{array}{c}26 \\
(52 \%)\end{array}$ & $\begin{array}{c}10 \\
(20 \%)\end{array}$ \\
\hline \multirow{2}{*}{3} & $\begin{array}{l}\text { It takes a lot of time to review knowledge } \\
\text { and practice math skills for students. }\end{array}$ & $\begin{array}{c}1 \\
(2 \%)\end{array}$ & $\begin{array}{c}5 \\
(10 \%)\end{array}$ & $\begin{array}{c}4 \\
(8 \%)\end{array}$ & $\begin{array}{c}24 \\
(48 \%)\end{array}$ & $\begin{array}{c}16 \\
(32 \%)\end{array}$ \\
\hline
\end{tabular}

Data in Table 1 reveals that more than $68 \%$ of teachers agree or fully agree that teaching with multiple choice questions, it takes much time for teachers to prepare lessons and review; at the same time, teachers must change teaching methods to suit this form because students cannot solve these questions in a familiar way like doing essay questions; therefore, it requires great effort of both teachers and students in the first years of familiarization with this method. This is really a big challenge for teachers in the early years to get acquainted with this form when evaluating the knowledge and skills of the student is more extensive and diverse in many aspects.

Table 2. Comments about creating the test using multiple-choice questions

\begin{tabular}{|c|c|c|c|c|c|c|}
\hline & Items & Strongly disagree & Disagree & Neutral & Agree & Strongly agree \\
\hline 1 & $\begin{array}{l}\text { 1Spend a lot of time designing an exam with } \\
\text { multiple choice questions }\end{array}$ & $\begin{array}{c}0 \\
(0 \%) \\
\end{array}$ & $\begin{array}{c}5 \\
(10 \%) \\
\end{array}$ & $\begin{array}{c}5 \\
(10 \%) \\
\end{array}$ & $\begin{array}{c}24 \\
(48 \%) \\
\end{array}$ & $\begin{array}{c}16 \\
(32 \%) \\
\end{array}$ \\
\hline 2 & $\begin{array}{l}\text { The difficulty of designing multiple-choice } \\
\text { questions according to different difficulty levels }\end{array}$ & $\begin{array}{c}0 \\
(0 \%)\end{array}$ & $\begin{array}{c}2 \\
(4 \%) \\
\end{array}$ & $\begin{array}{c}8 \\
(16 \%) \\
\end{array}$ & $\begin{array}{c}21 \\
(42 \%) \\
\end{array}$ & $\begin{array}{c}19 \\
(38 \%) \\
\end{array}$ \\
\hline 3 & $\begin{array}{l}\text { Difficulties in creating distractors in multiple } \\
\text { choice questions }\end{array}$ & $\begin{array}{c}1 \\
(2 \%) \\
\end{array}$ & $\begin{array}{c}1 \\
(2 \%) \\
\end{array}$ & $\begin{array}{c}0 \\
(0 \%) \\
\end{array}$ & $\begin{array}{c}36 \\
(72 \%) \\
\end{array}$ & $\begin{array}{c}12 \\
(24 \%) \\
\end{array}$ \\
\hline 4 & Grading test quickly if using grading machine & $\begin{array}{c}0 \\
(0 \%) \\
\end{array}$ & $\begin{array}{c}0 \\
(0 \%) \\
\end{array}$ & $\begin{array}{c}4 \\
(8 \%) \\
\end{array}$ & $\begin{array}{c}25 \\
(50 \%) \\
\end{array}$ & $\begin{array}{c}22 \\
(42 \%) \\
\end{array}$ \\
\hline
\end{tabular}

As an inevitable consequence, the difficulty of teaching will entail specific difficulties for examination and evaluation. Because these two concepts are always parallel and closely related, it requires teachers to have the attention, proper investment in accordance with the actual situation of their students. The survey results, as shown in Table 2 , indicate that nearly $80 \%$ of teachers agree or fully agree that testing using multiple choice questions is time-consuming for designing questions, it is not easy to construct questions with different levels of difficulty (about $80 \%$ teachers agree or totally agree). In particular, $96 \%$ of teachers agreed that they had difficulty in making distractors. And $92 \%$ of teachers agree that grading test is quickly in a case of using grading machine,

We believe that the above difficulties are temporary because once the bank of multiple-choice questions is built to be suitable and standardized, and especially with the support of information technology, the tasks of organizing testing and evaluation will become easier. 
Table 3. Opinions about students' learning attitudes in the case of using multiple-choice questions in the exam

\begin{tabular}{|c|c|c|c|c|c|c|}
\hline & Items & $\begin{array}{l}\begin{array}{l}\text { Strongly } \\
\text { disagree }\end{array} \\
\end{array}$ & Disagree & Neutral & Agree & $\begin{array}{c}\begin{array}{c}\text { Strongly } \\
\text { agree }\end{array} \\
\end{array}$ \\
\hline 1 & $\begin{array}{l}\text { Students feel the pressure from the knowledge level on the } \\
\text { multiple-choice question based - exams to be more spread } \\
\text { out than the essay exams. }\end{array}$ & $\begin{array}{c}0 \\
(0 \%)\end{array}$ & $\begin{array}{c}5 \\
(10 \\
\%)\end{array}$ & $\begin{array}{c}7 \\
(14 \%)\end{array}$ & $\begin{array}{c}28 \\
(56 \%)\end{array}$ & $\begin{array}{c}10 \\
(20 \%)\end{array}$ \\
\hline 2 & $\begin{array}{l}\text { Students with low or average learning ability prefer to take } \\
\text { the test in the form of multiple-choice questions than } \\
\text { students who are quite excellent or good. }\end{array}$ & $\begin{array}{c}1 \\
(2 \%)\end{array}$ & $\begin{array}{c}9 \\
(14 \%)\end{array}$ & $\begin{array}{c}4 \\
(8 \%)\end{array}$ & $\begin{array}{c}21 \\
(42 \%)\end{array}$ & $\begin{array}{c}17 \\
(34 \%)\end{array}$ \\
\hline 3 & $\begin{array}{l}\text { Students have subjective psychology of learning because } \\
\text { the test has the correct probability even if they do not know } \\
\text { how to solve }\end{array}$ & $\begin{array}{c}0 \\
(0 \%)\end{array}$ & $\begin{array}{c}5 \\
(10 \%) \\
\end{array}$ & $\begin{array}{c}3 \\
(6 \%)\end{array}$ & $\begin{array}{c}30 \\
(60 \%) \\
\end{array}$ & $\begin{array}{c}12 \\
(24 \%) \\
\end{array}$ \\
\hline 4 & $\begin{array}{l}\text { Students feel confused when in the process of studying, } \\
\text { sometimes take the essay test, sometimes take the } \\
\text { multiple-choice test }\end{array}$ & $\begin{array}{c}0 \\
(0 \%)\end{array}$ & $\begin{array}{c}4 \\
(8 \%)\end{array}$ & $\begin{array}{c}12 \\
(24 \%)\end{array}$ & $\begin{array}{c}27 \\
(54 \%)\end{array}$ & $\begin{array}{c}7 \\
(14 \%)\end{array}$ \\
\hline 5 & $\begin{array}{l}\text { Students are stressed about time with multiple choice } \\
\text { question-based test because there are too many questions to } \\
\text { answer in a short time. }\end{array}$ & $\begin{array}{c}1 \\
(2 \%)\end{array}$ & $\begin{array}{c}4 \\
(8 \%)\end{array}$ & $\begin{array}{c}9 \\
(18 \%)\end{array}$ & $\begin{array}{c}24 \\
(48 \%)\end{array}$ & $\begin{array}{c}12 \\
(24 \%)\end{array}$ \\
\hline
\end{tabular}

Through Table 3, it can be seen that more than $70 \%$ of teachers realized that their students were under pressure with the amount of knowledge and skills which they need to be fluent in each exam; at the same time, the pressure is not small in terms of time in each test. And a total of $84 \%$ of teachers said that students' learning attitude tended to be subjective in their process of learning in a case of taking exam using multiple-choice questions because the test has the correct probability even if they do not know how to solve; however, through experience, in order to get good grades, they must have enough knowledge and skills; i.e. they must undergo a rigorous learning process. But we think these are just obstacles in the students' first mentality. As we know that students' academic achievements depend on many other factors such as classroom management skills, teaching methods of the teachers, if the teachers have enough knowledge, skills and dedication in teaching, they can still attract students in their lessons. Since then gradually overcome and help the students overcome obstacles.

Table 4. Effectiveness of using multiple-choice questions in exams

\begin{tabular}{|c|c|c|c|c|c|c|}
\hline & Items & Strongly disagree & Disagree & Neutral & $\begin{array}{c}\text { Agree } \\
\text { Strongly } \\
\text { agree }\end{array}$ \\
\hline 1 & $\begin{array}{c}\text { The multiple-choice question-based test format } \\
\text { ensures objectivity in the grading process }\end{array}$ & $\begin{array}{c}1 \\
(2 \%)\end{array}$ & $\begin{array}{c}5 \\
(10 \%)\end{array}$ & $\begin{array}{c}2 \\
(4 \%)\end{array}$ & $\begin{array}{c}36 \\
(72 \%)\end{array}$ & $\begin{array}{c}6 \\
(12 \%)\end{array}$ \\
\hline 2 & $\begin{array}{c}\text { Student cheating is hard to occur in exams with the } \\
\text { multiple-choice questions }\end{array}$ & $\begin{array}{c}10 \% \\
(\%)\end{array}$ & $\begin{array}{c}20 \\
(40 \%)\end{array}$ & $\begin{array}{c}14 \\
(28 \%)\end{array}$ & $\begin{array}{c}15 \\
(30 \%)\end{array}$ & $\begin{array}{c}1 \\
(2 \%)\end{array}$ \\
\hline 3 & $\begin{array}{c}\text { Exams with multiple- choice questions do not test } \\
\text { students' thinking and logical reasoning ability. }\end{array}$ & $\begin{array}{c}1 \\
(4 \%)\end{array}$ & $\begin{array}{c}10 \\
(20 \%)\end{array}$ & $\begin{array}{c}2 \\
(4 \%)\end{array}$ & $\begin{array}{c}22 \\
(44 \%)\end{array}$ & $\begin{array}{c}14 \\
(28 \%)\end{array}$ \\
\hline 4 & $\begin{array}{c}\text { The results of the National Exam with } \\
\text { multiple-choice questions can be used to select } \\
\text { students to study at Colleges and Universities. }\end{array}$ & $\begin{array}{c}11 \\
(10 \%)\end{array}$ & $\begin{array}{c}14 \\
(22 \%)\end{array}$ & $\begin{array}{c}16 \%) \\
(32 \%)\end{array}$ & $(8 \%)$ \\
\hline
\end{tabular}

Perhaps when it comes to objectivity and fairness, these are the delicate things of life. The survey results (see Table 4) show that $84 \%$ of teachers agree or completely agree with using multiple choice question based - test to ensure objectivity. But, only $32 \%$ of teachers agree that the test limits student cheating. Up to $72 \%$ of teachers agree that the kind of test cannot evaluate students' thinking and reasoning ability; this is the reason why some people are unconvinced, especially in math. In particular, no more than half of the teachers agreed to use the results of the national exam for admission to universities and colleges. One thing should be taken notice of that some teachers also suggest that the Ministry of Education and Training should apply the method of giving negative marks to the questions that students make wrong to eliminate the probability of luck so that the test of mathematics will have better.

Table 5. Comments on the use of the type of Math questions in national exams

\begin{tabular}{|c|l|c|c|c|c|c|}
\hline & \multicolumn{1}{|c|}{ Items } & $\begin{array}{c}\text { Strongly } \\
\text { disagree }\end{array}$ & Disagree & Neutral & Agree & Strongly agree \\
\hline 1 & $\begin{array}{l}\text { Continue to use } 100 \% \text { multiple- choice questions in } \\
\text { each exam }\end{array}$ & $\begin{array}{c}5 \\
(10 \%)\end{array}$ & $\begin{array}{c}11 \\
(22 \%)\end{array}$ & $\begin{array}{c}19 \\
(18 \%)\end{array}$ & $\begin{array}{c}25 \\
(50 \%)\end{array}$ & $\begin{array}{c}2 \\
(4 \%)\end{array}$ \\
\hline 2 & $\begin{array}{l}\text { Include both essay and multiple-choice questions in } \\
\text { each exam }\end{array}$ & $\begin{array}{c}5 \\
(10 \%)\end{array}$ & $\begin{array}{c}15 \\
(30 \%)\end{array}$ & $\begin{array}{c}14 \\
(28 \%)\end{array}$ & $\begin{array}{c}12 \\
(24 \%)\end{array}$ & $\begin{array}{c}4 \\
(8 \%)\end{array}$ \\
\hline 3 & $100 \%$ questions in each exam are essay questions & $\begin{array}{c}2 \\
(4 \%)\end{array}$ & $\begin{array}{c}10 \\
(20 \%)\end{array}$ & $\begin{array}{c}20 \\
(40 \%)\end{array}$ & $\begin{array}{c}10 \\
(20 \%)\end{array}$ & $\begin{array}{c}8 \\
(16 \%)\end{array}$ \\
\hline
\end{tabular}


In this section, for national examinations, we introduced three choices: (1) continue to maintain the $100 \%$ test using multiple-choice questions; (2) combine essay and multiple-choice questions; the last is to return to the $100 \%$ essay form as many years ago. The results in Table 5 were surprising because only the first choice received the support of more than $50 \%$ of teachers participating in the survey while about $32 \%$ for (2) and $28 \%$ for (3). Explaining this issue, we think that it is possible for the following reasons:

- After two years of using the test in the form of multiple-choice questions, all preparation stages are almost completed and entered into a specific framework.

- If continued to change, more or less will continue to cause disturbance and worry for students and everyone concerned. Especially in the education sector is in a sensitive period as today in Vietnam. We recognize that the important thing is still in the stage of building the bank of appropriate questions and how to organize exams so that they still ensure the fairness and objectivity for students.

\section{Conclusions}

Through the survey results presented above, the majority of math teachers concur the core points of a national examination that are required: Ensuring objectivity, comprehensively testing knowledge and skills, marking time must be fast. Although it is hard to practice for students to master knowledge and skills in a large area, most teachers still agree highly in organizing national mathematics exams with multiple-choice questions.

In our opinion, if well prepared, the multiple-choice question-based test has many advantages. Some of the main advantages are as follows:

1) This is an appropriate form when there is a large number of students take an examination as a case of the national examination in Vietnam because its goal is not to find the most gifted students in mathematics.

2) The advantage of a multiple-choice question-based exam is that it tests the students' ability to guess, estimate, and make quick decisions. These skills are the basic skills necessary for everyone, maybe more important than the ability to solve a complete problem from A to $\mathrm{Z}$.

3) Do not worry "rote learning, memorizing", because if students "memorize" that they can do all kinds of exercises, it is entirely worthy of standard. In addition, for mathematics, if you do not understand the nature of a concept or a theorem, it is difficult to memorize all the knowledge, because a primary problem (such as solving the system of first-degree equations) can be expressed in many forms.
4) The grading process is speedy and secure.; avoiding subjective and unfair factors. This advantage is superior to the assessment of essay questions.

5) Vietnamese educators need to build good enough. Students in schools also need to familiarize themselves with this test through periodic tests. Once students, teachers, and parents have understood the test well and are well-prepared technically and psychologically, it will be easier to achieve the goal of a national examination.

\section{REFERENCES}

[1] Thuy Linh (2019). Professor of Mathematics who cannot solve general Math problems is very normal. Education Daily News. Online (06/11/2019) Available from http://giaoduc.net .

[2] Nguyen Hung (2007). Multiple-choice question-based math test: Limiting creativity and logical thinking? Dan Tri Daily News Online, (29/10/2019), https://dantri.com.vn/giao-duc-khuyen-hoc/thi-trac-nghiem -mon-toan-han-che-tinh-sang-tao-va-tu-duy-logic-1193749 379.htm

[3] Centre for teaching excellence- University of Waterloo (Canada), Exam Questions: Types, Characteristics, and Suggestions. Online Available from:https://uwaterloo.ca/centre-for-teaching-excellence/te aching-resources/teaching-tips/developing-assignments/ex ams/questions-types-characteristics-suggestions

[4] Maryellen Weimer (2018).Advantages and Disadvantages of Different Types of Test Questions. Online Available from

https://www.facultyfocus.com/articles/educational-assessm ent/advantages-and

disadvantages-of-different-types-of-test-questions/

[5] Merriam-Webster Dictionary. Online Available from: https://www.merriam -webster.com/dictionary/essay\%20question

[6] My Ha (2016) . Prof. Ngo Bao Chau: Some countries tend to use multiple choice question-based test for Math examination, Dan Tri Daily News Online (11/9/2016). Online Available from https://dantri.com.vn/giao-duc-khuyen-hoc/gs-ngo-bao-cha u-mot-so-nuoc-co-xu-the-thi-trac-nghiem-toan-201609111 82928218.htm

[7] Ramezan Jahanian (2012). Educational Evaluation: Functions and Applications in Educational Contexts, International Journal of Academic Research in Economics and Management Sciences, April 2012, Vol. 1, No. 2

[8] Cambridge Dictionary. Online Available from https://dictionary.cambridge.org/

[9] Rijal Firdaos \& Ahmad (2018), "The implementation of national examination as the direction of national education policy", Al-Tadzkiyyah: Jurnal Pendidikan Islam, Volume 9, Edisi I 2018) 
[10] Reuben Nguyo Wachiuri, Badari Shisha, L.Nonglait, Jedidah Nyawira Kimathi (2017). To Determine the Effects of the Role of Examinations on the Development of All-Inclusive Learners in Secondary Schools Nyeri County, Kenya IOSR Journal of Research \& Method in Education (IOSR-JRME) e-ISSN: 2320-7388,p-ISSN: 2320-737X Volume 7, Issue 3 Ver. I (May. - June. 2017), PP 62-65.

[11] Sukyadi, D., \& Mardiani, R. (2011). The Washback Effect of the English National Examination (ENE) on English Teachers' Classroom Teaching and Students' Learning., K@ta,13(1), 96-111. Retrieved January 10, 2020. 